\title{
Geochemical insights into the distinct mantle sources of coeval shoshonitic lamprophyres and kimberlites from the Wajrakarur kimberlite field, Dharwar Craton
}

\author{
ASHUTOSH PANDEY ${ }^{1 *}$, N.V. CHALAPATHI RAO ${ }^{1}$
}

${ }^{1}$ Department of Geology, Institute of Science, Banaras Hindu University, Varanasi 221005, India (*correspondance: ashutoshpandey2111@gmail.com)

The Eastern Dharwar Craton (EDC) of the southern Indian shield host numerous Mesoproterozoic ( 1100 Ma) kimberlite fields. Shoshonitic lamprophyre dykes synchronous to these kimberlites are exposed in the diamondiferous Wajrakarur kimberlite field (WKF). These lamprophyre dykes are characterized by the presence of olivine, biotite and zoned clinopyroxene phenocrysts set in a groundmass of feldspar, spinel and apatite. High $\mathrm{K}_{2} \mathrm{O} / \mathrm{Na}_{2} \mathrm{O}$ (1.5-3.4) along with elevated Th content $(2.2-8.6)$ in these dykes reveal their shoshonitic affinity. High $\mathrm{Th} / \mathrm{Yb}$ (1.5-4.1), $\mathrm{Nb} / \mathrm{Yb}$ (23.8-59.0) and superchondritic $\mathrm{Zr} / \mathrm{Hf}$ ratios (40-50.4) similar to the oceanic island basalts rules out crustal assimilation and highlights the role of an enriched mantle source in their genesis.

Age corrected bulk-rock $\varepsilon N d$ of the shoshonitic lamprophyres vary between -13.73 and -22.90 , whereas the initial ${ }^{87} \mathrm{Sr} /{ }^{86} \mathrm{Sr}$ ranges between and $0.70533-0.71218$ suggesting their derivation from an enriched lithospheric mantle. However, the coeval kimberlites of the WKF have distinct $\mathrm{Sr}-\mathrm{Nd}$ isotopic composition with bulk-rock $\varepsilon \mathrm{Nd}$ and initial ${ }^{87} \mathrm{Sr} /{ }^{86} \mathrm{Sr}$ varying from 0.44 to 2.75 and 0.70209 to 0.70744 , respectively, similar to that of the groundmass perovskite $\varepsilon \mathrm{Nd}(2.08-2.92)$ and initial ${ }^{87} \mathrm{Sr} /{ }^{86} \mathrm{Sr}(0.70234$ $0.70255)$. Since, these kimberlites tap an isotopically depleted mantle source, unlike the shoshonitic lamprophyres, the geochemistry of these rocks points to a vertically heterogeneous lithospheric mantle beneath the EDC. We suggest that the Wajrakarur kimberlites generated from a deeper depleted mantle $(>150 \mathrm{~km})$ compared to the shallower enriched lithospheric mantle source for the shoshonitic lamprophyres. Neoarchean (2.6-2.8 Ga) Nd depleted mantle model ages for these lamprophyres suggest that the subcontinental lithospheric mantle was enriched during Neoarchean accretion-related evolution of the Dharwar Craton. 